\title{
Impact Of Ingráfica Festival In The City Of Cuenca (Spain)
}

Manuel Vargas-Vargas, Ph.D., University of Castilla-La Mancha, Spain José Mondéjar-Jiménez, Ph.D., University of Castilla-La Mancha, Spain Leticia Meseguer-Santamaría, University of Castilla-La Mancha, Spain Santiago Yubero-Martínez, Ph.D., University of Castilla-La Mancha, Spain Elisa Larrañaga-Rubio, Ph.D., University of Castilla-La Mancha, Spain

\begin{abstract}
Ingráfica, International Festival of Contemporary Engraving City of Cuenca, is an international platform to support the creation, promotion and dissemination of contemporary printmaking and other forms of multiple art. Its purpose is to reflect on the engraving as an artistic discipline of XXI century, acting as a meeting point and consultation between the professionals and concerned citizens recorded in going in this artistic discipline and its variants. Ingráfica is the only noncommercial event with the world of graphic, which is held annually in Spain. The main aim of this paper is to determine the impact of Ingráfica in the city of Cuenca, with a view to taking appropriate strategies to the profile of the attendees. It also wants to know the satisfaction of visitors with different activities of Ingráfica.
\end{abstract}

Keywords: Ingráfica, tourism and impact.

\section{INTRODUCTION}

$\mathscr{I}$ ngráfica is a project designed and organized by Hablar en Arte, cultural non-profit association dedicated to the promotion, development, research, protection and dissemination of activities related to the visual arts, performing and visual. The festival is sponsored by the Council of Cuenca and has the support of the Consorcio of the city, which includes the central government, the regional government (Junta de Comunidades de Castilla-La Mancha), the Diputación Provincial de Cuenca and the City Council. In the 2009 edition are also sponsoring the festival, the University of Castilla-La Mancha, the Romanian Cultural Institute, the Austrian Cultural Forum, the Polish Institute in Madrid and the Italian Institute of Culture in Madrid. Partners are the Social and Cultural Work of CCM, the Instituto Cervantes and the Chamber of Commerce Polish-Spanish.

Ingráfica is one of cultural events designed to boost the aspirations of Cuenca to get the Capital of Culture in 2016, with the intent to promote the vision of a city committed to the culture for the outside. The fact that the festival (Ingráfica on Open) is integrated into the Triennial of Engraving of Krakow, one of the most prestigious events recorded in Europe and the agreements reached Ingráfica to raise awareness abroad of the hand of the Institute Cervantes, are contributing to the name of Cuenca heard for much of the world.

The specific aims of this paper are, in line with other similar work (Devesa, 2006; Herrero, 2004; Perles, 2006):

- $\quad$ To know the brand image Ingráfica.

- $\quad$ To know the Ingráfica visitor profile.

- $\quad$ To study the visitor' satisfaction with the visits to exhibitions and activities of Ingráfica, getting to know the weaknesses and try to fix in future editions.

From the viewpoint of planning and touristic destination management should pay special attention to the maintenance and conservation of natural resources representing the tourism (Lopez Bonilla and Lopez Bonilla, 
2007), yet must agglutinate management tools that enable adequate provision of resources (Mondéjar, Mondéjar, Sevilla and Cordente, 2009), which neatly channeled different policies to support the tourism sector and, especially, in this sense, the traditional cyclical behavior of the touristic sector can be seasonally adjusted by the emergence of new tourist products, which create significant market segments for the sector, such as the celebration of different events (Mondéjar, Mondéjar and Sevilla, 2009).

\section{METHODOLOGY}

To achieve the stated objectives, this research has been designed to know details about the degree of knowledge of Ingráfica, the valuation of its image, participation in scheduled activities and the assessment of their quality. The information is obtained by personal interviews with visitors attending exhibitions and activities, selected randomly and trying to get a representative sample.

As result, 195 questionnaires were obtained, with whom, for a number attendees around 10,000, a sample size of 195 individuals would provide an initial error of $\pm 6.9 \%$, with a confidence level of $95 \%$ for a variable with two categories equally likely $(\mathrm{p}=\mathrm{q}=0.5)$. We show that the Festival Ingráfica, often a blend of museums and prestigious rooms in our city, although, as is clear from the data, a large majority of respondents know the festival. Table 1 shows the most important characteristics of the sample design and data collection fieldwork of this study.

Table 1: Technical Data

\begin{tabular}{|l|c|}
\hline Population & Attendees at II Festival Ingráfica \\
\hline Methodology & Personal interviews by structured questionnaire \\
\hline Sample Size & 195 valid questionnaires \\
\hline Sampling Error & $\pm 6,9 \%$ \\
\hline Confidence Level & $95 \%(\mathrm{p}=\mathrm{q}=0,5)$ \\
\hline Data Collection & November 14 to December 13,2009 \\
\hline
\end{tabular}

\section{RESULTS}

The Ingráfica attendee profile has the following significant features (see Table 2):

Table 2: Socio demographics Data

\begin{tabular}{|c|c|c|}
\hline \multicolumn{1}{|c|}{ Table 2: Socio demographics Data } & Percentage (\%) \\
\hline Variable & Characteristics & $\mathbf{5 0 , 9}$ \\
\hline \multirow{2}{*}{ Gender } & Male & 6,1 \\
\hline \multirow{2}{*}{ Age } & Female & $\mathbf{6 2 , 7}$ \\
& $>25$ years & 28,2 \\
& $\mathbf{2 5 - 4 4}$ years & 2,7 \\
\hline \multirow{2}{*}{ Education Level } & $45-65$ years & 0,9 \\
& $<65$ years & 12,7 \\
& Primary & $\mathbf{8 6 , 4}$ \\
& Secondary & 35,5 \\
& University & 10,9 \\
\end{tabular}

More than $80 \%(81.8 \%)$ of people knew Ingráfica, but only $63.6 \%$ recognized his brand image. In general, the score of the logo is positive in all aspects evaluated. In the comparison between the opinions of those who previously knew Ingráfica and the unknown, the former have a more consolidated scoring (5.21). This is the only significant difference found between the two groups $(\mathrm{t}=2.25, \mathrm{p}<, 027)$. As shown in Figure 1, looking at the brand image, taking into account the sex of respondents, the score of women is slightly higher than men. 
If we analyze the experience by gender, more women attend for the first time. However, this relationship is not statistically significant. The analysis of the experience by age shows that after 25 years, as age increases, the greater the percentage already attended the previous edition. Those attending for the first time are more young people, mostly between 25 and 44 . This relationship is significant at $95 \%$.

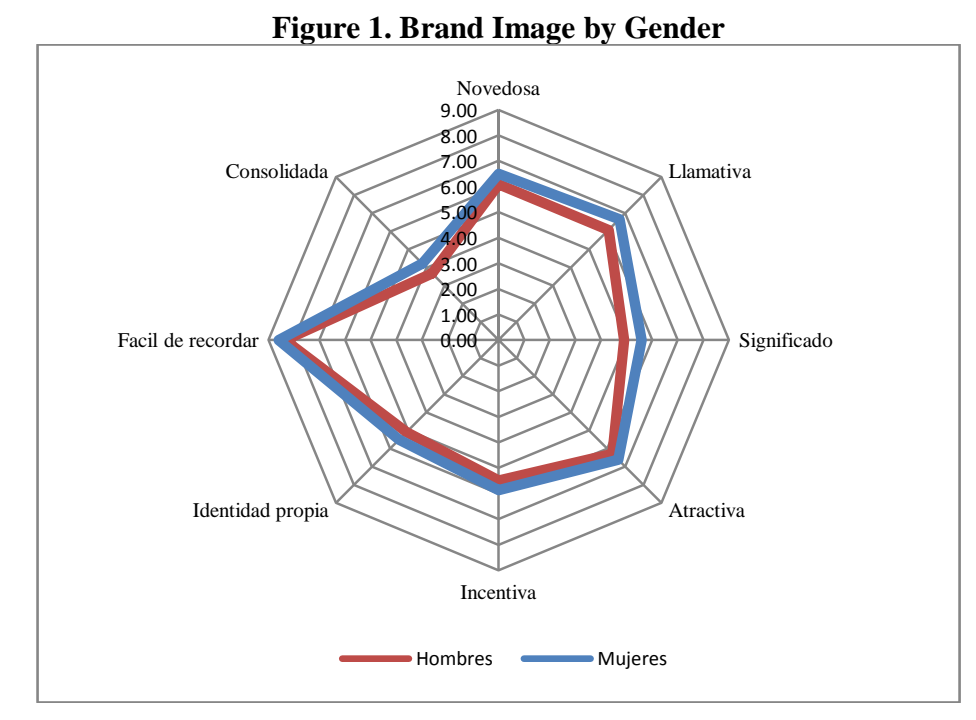

As shown in Figure 2, the main reason to visit Ingráfica is in the answer category 'other', with $43.6 \%$. Then, we disaggregate this option. From the analysis of data, it appears that the main reason that motivated the visit to Ingráfica was the recommendation of friends and relatives (29.1\%), followed, secondly, by information in mass media (15.5\%). Internet, with almost $12 \%$, is placed as a source of information suitable for dissemination. Also prominently is the assistance of those who were visiting Cuenca during the weekend in which the information was collected.

Figure 2: Reason to visit Ingráfica

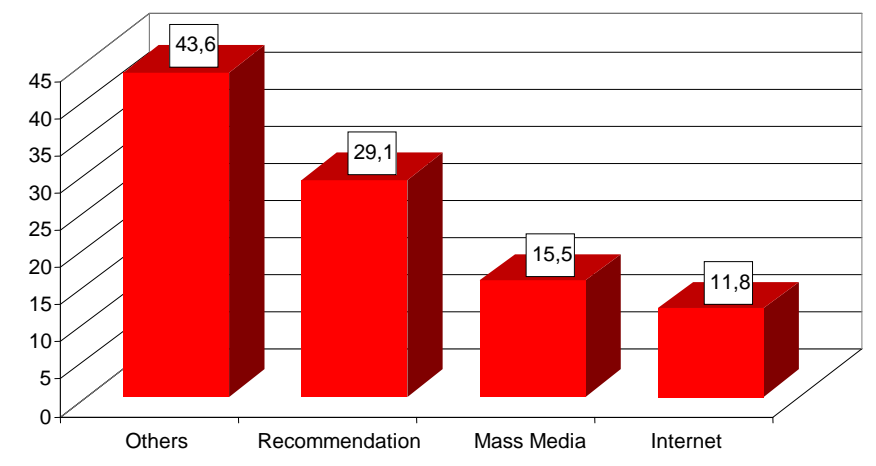

The opinion of the assistants on Ingráfica is quite positive, reaching a score of 7.54 over 10 points. The most common ratings are distributed among those who scored 7 (26.4\%), 8 points (20\%) and 9 points to $14.5 \%$ of the attendees. $4.5 \%$ pays less than 5 points to Ingráfica (a score which represents only 8 persons). If we analyze the score of Ingráfica according to sociodemographic variables and experience (see Table 3), although there are slight variations among the participants, none reached statistical significance. 
Table 3: Score of Ingráfica, socio-demographic variables

\begin{tabular}{|c|c|c|c|c|}
\hline Variable & Characteristics & Mean & Test & p-value \\
\hline Gender & $\begin{array}{c}\text { Male } \\
\text { Female }\end{array}$ & $\begin{array}{l}7,25 \\
7,83\end{array}$ & $-1,61$ &, 110 \\
\hline Age & $\begin{array}{c}>25 \text { years } \\
25-44 \text { years } \\
45-65 \text { years } \\
<65 \text { years }\end{array}$ & $\begin{array}{l}6,57 \\
7,52 \\
7,74 \\
8,00\end{array}$ & 0,77 & ,767 \\
\hline Education Level & $\begin{array}{c}\text { Primary } \\
\text { Secondary } \\
\text { University } \\
\end{array}$ & $\begin{array}{l}6,00 \\
7,21 \\
7,60 \\
\end{array}$ & 0,57 & ,568 \\
\hline Residence & $\begin{array}{c}\text { Cuenca } \\
\text { Castilla-La Mancha } \\
\text { Spain } \\
\text { Foreign }\end{array}$ & $\begin{array}{l}7,00 \\
7,58 \\
7,82 \\
8,75\end{array}$ & 2,01 &, 117 \\
\hline Experience & $\begin{array}{c}\text { First attendee } \\
\text { Previous attendee }\end{array}$ & $\begin{array}{l}7,58 \\
7,46\end{array}$ & 0,31 & ,758 \\
\hline
\end{tabular}

\section{CONCLUSIONS}

From the information collected in this study, the main conclusions and recommendations of this research can be summarized in the following points:

1. The most frequent profile among Ingráfica attendees is an individual between 25 and 44 years old, with university education and defined cultural interests.

2. The study indicates that Ingráfica is on a firm path of consolidation, demonstrating a high capacity for loyalty to the attendees. Thus, $97.6 \%$ of those attending the two editions of the festival said he would return next year. They also say they would return for the 2010 edition the $82.6 \%$ of those who have attended for the first time Ingráfica in 2009. Thus, this festival consolidates as a platform of Spanish contemporary printmaking.

3. Following on the previous line, $37.3 \%$ of the participants in 2009 had attended the festival last year.

4. In relation to its relevance as a platform of art, $21.8 \%$ of the attendees of this year have moved to Cuenca to attend Ingráfica. This fact makes clear how these activities can be an additional tourist attraction to be the main reason for the visit to the city of more than one-fifth of the respondents.

5. Attendees at this edition of Ingráfica appreciate the festival with an average rating of 7.54 over 10, showing their satisfaction with the assistance. The obtained a score above 7 is ratified in the various segments studied by different classification questions provided in the questionnaire.

6. All activities in Ingráfica reach an average score above 7. The highest score they receive exposures.

7. The valuation of festival brand is positive. The weakest areas relate to her self-identity and brand building.

8. The assessment of brand image has been very positive. Without being a specialist public in such valuations, in general, and despite the confusion of many respondents with other logos, has managed to create brand image: one action that it would consolidate its should be the inclusion in every festival activities.

9. The overall satisfaction of attendees to the celebration of the festival and the environment in which it occurs is high, which implies that $94 \%$ of attendees would recommend to family and friends attending Ingráfica and, similarly, invited to visit Cuenca as a tourist destination.

10. Over $80 \%$ of the participants believe that an advertising effort would increase the number of visitors. Although the recommendation of the interest of the festival has been the main reason they have attended for the first time Ingráfica (29.1\%), the broadcast media and the Internet has also proved effective.

11. Undoubtedly, considering the obtained results, is necessary to continue Ingráfica experience. We cannot forget that this is only the second year of the festival.

12. Wider diffusion of programs and activities (exhibitions, tours, etc.) can lead to greater citizen participation. Although this year adding a number of works at bus stops, murals and other, many people have not been able to associate them in the city, so the public assistance of the City of Cuenca itself is well below that of other similar events. 


\section{AUTHOR INFORMATION}

Manuel Vargas-Vargas: PhD in Economics by University of Castilla-La Mancha and Degree in Mathematics by University of Granada. Associate Professor in Statistics at Statistics Department. Faculty of Economics and Business Administration of Albacete, University of Castilla-La Mancha (Spain). E-mail: Manuel.Vargas@uclm.es. Research Interest: disability, regional analysis, educational and tourism.

José Mondéjar-Jiménez: European $\mathrm{PhD}$ in Economics and Degree in Business Administration by University of Castilla-La Mancha. Associate Professor at Statistics Department. Faculty of Social Sciences of Cuenca. University of Castilla-La Mancha (Spain). E-mail: Jose.Mondejar@uclm.es.

Research Interest: disability, regional analysis, educational and tourism.

María-Leticia Meseguer-Santamaría: MBA in Economics Degree in Business Administration by University of Castilla-La Mancha. Assistant Professor in Statistics at Statistics Department. Faculty of Economics and Business Administration of Albacete. University of Castilla-La Mancha (Spain). E-mail: MLeticia.Meseguer@uclm.es.

Research Interest: disability, women studies, educational and tourism.

Santiago Yubero-Jiménez: PhD in Psychology. Professor at Psychology Department. Faculty of Education and Humanities of Cuenca. University of Castilla-La Mancha (Spain). E-mail: Santiago.Yubero@uclm.es.

Research Interest: Psychology and education.

Elisa Larrañaga-Rubio: $\mathrm{PhD}$ in Psychology. Associate Professor at Psychology Department. School of Social Work of Cuenca. University of Castilla-La Mancha (Spain). E-mail: Elisa.Larranaga@ uclm.es.

Research Interest: Psychology and education.

\section{REFERENCES}

1. Devesa, M. (2006): El impacto económico de los festivales culturales: el caso de la Semana Internacional de Cine de Valladolid. Madrid: Iberautor Promociones Culturales S.L.

2. Herrero, L. C. (2004): "Impacto económico de los macrofestivales culturales: reflexiones y resultados", Portal Iberoamericano de Gestión Cultural.

3. Perles, J. F. (2006): “Análisis del impacto económico de eventos: una aplicación a fiestas populares de proyección turística", Cuadernos de Turismo, 17, pp. 147-166.

4. López, J. M. and López, L. M. (2007): "Diferencias territoriales en la planificación y la gestión del destino turístico", Cuadernos de Turismo, 19, pp. 45-59.

5. Mondéjar, J. A.; Mondéjar, J. and Sevilla, C. (2008): "El turismo de reuniones y congresos en Cuenca: una visión de síntesis". In López, D. (ed.): Turismo de negocios y reuniones: Convenciones, congresos e incentivos. Valencia: Tirant lo Blanch.

6. Mondéjar, J. A.; Mondéjar, J.; Sevilla, C. and Cordente, M. (2009): "La Fundación Turismo de Cuenca: Un nuevo modelo de gestión pública y privada". PASOS, Revista de Turismo y Patrimonio Cultural, vol. 7, $\mathrm{n}^{\circ}$ 2, pp. 281-296.

7. Yubero, S.; Larrañaga. E.; Vargas, M.; Mondéjar, J. and Meseguer, M. L. (2010): “Análisis del impacto de Ingráfica 2009”. Cuenca: Universidad de Castilla-La Mancha, Observatorio de Políticas Culturales. 
NOTES 